\title{
PENGARUH KOMUNIKASI, DISIPLIN KERJA, DAN KOMPENSASI TERHADAP KINERJA KARYAWAN WARUNG MAK BENG CABANG UBUD
}

\author{
Meira Rofianti ${ }^{1}$ \\ I Gusti Ayu Manuati Dewi \\ ${ }^{1,2}$ Fakultas Ekonomi dan Bisnis, Universitas Udayana, Bali-Indonesia \\ email:mrofianti@gmail.com
}

\begin{abstract}
ABSTRAK
Kinerja adalah hasil kerja secara kualitas dan kuantitas yang dicapai oleh seorang karyawan dalam melaksanakan tugasnya sesuai dengan tanggung jawab yang diberikan. Penelitian ini bertujuan untuk menganalisis pengaruh komunikasi, disiplin kerja, dan kompensasi terhadap kinerja karyawan. Lokasi penelitian adalah Warung Mak Beng Cabang Ubud. Metode penentuan dengan sampling jenuh dimana seluruh populasi dijadikan sampel. Jumlah responden dalam penelitian yaitu 40 orang. Pengumpulan data dilakukan melalui wawancara dan penyebaran kuesioner. Teknik analisis data yang digunakan adalah Regresi Linier Berganda. Hasil penelitian menunjukkan bahwa komunikasi, disiplin kerja, dan kompensasi berpengaruh positif dan signifikan terhadap kinerja karyawan Warung Mak Beng Cabang Ubud. Upaya peningkatan kinerja karyawan pada perusahaan dapat ditingkatkan dengan menjalin komunikasi yang baik antar karyawan, menaati peraturan yang ditetapkan perusahaan, dan kompensasi yang adil sesuai dengan beban kerja.

Kata kunci : komunikasi, disiplin kerja, kompensasi, kinerja karyawan
\end{abstract}

\begin{abstract}
Performance is the result of quality and quantity of work achieved by an employee in carrying out their duties in accordance with the responsibilities given. This study aims to analyze the effect of communication, work discipline, and compensation on employee performance. The research conducted at Warung Mak Beng, Ubud.. The number of respondents in the study are 40 people using saturated sampling. Data collection was carried out through interviews and questionnaires. The data analysis technique used is Multiple Linear Regression. The results shows that communication, work discipline, and compensation have positive and significant effect on the performance of Warung Mak Beng employees. Efforts to improve employee performance at the company can be improved by establishing good communication between employees, obeying companydetermined regulations, and fair compensation in accordance with workload.

Keywords: communication, work discipline, compensation, employee performance
\end{abstract}




\section{PENDAHULUAN}

Sumber daya manusia (SDM) merupakan salah satu faktor penting yang menentukan kesuksesan sebuah organisasi. Setiap organisasi selalu berupaya untuk memperoleh SDM yang mampu membantu dalam usaha mencapai tujuan. SDM adalah harta atau aset yang paling berharga, dan paling penting dimiliki oleh suatu organisasi atau perusahaan, karena keberhasilan organisasi sangat ditentukan oleh unsur manusia. SDM berperan sebagai perencana, pelaksanaan, dan sekaligus pengendali terwujudnya tujuan organisasi atau perusahaan.

Organisasi yang baik adalah organisasi yang berusaha meningkatkan kemampuan SDM, karena hal tersebut merupakan faktor kunci untuk meningkatkan kinerja karyawan. Dampak positif akan dirasakan perusahan dengan meningkatnya kinerja karyawan. Oleh sebab itu, manajemen harus mampu mempelajari sikap serta perilaku karyawan dalam perusahaan untuk dapat mencapai tujuan dengan maksimal. Kinerja karyawan merupakan seberapa banyak seorang karyawan memberikan kontribusi kepada perusahaan yang meliputi aspek kuantitas output, kualitas output, jangka waktu, kehadiran ditempat kerja, dan sikap kooperatif. Kinerja juga perwujudan kerja yang dilakukan oleh karyawan yang biasanya dipakai sebagai dasar penilaian terhadap karyawan atau organisasi. Rendahnya kinerja karyawan juga disebabkan karena tugas dan pekerjaan yang dibebankan kepada karyawan cukup banyak, sehingga waktu untuk memberikan dukungan ataupun dorongan kepada rekan kerja hampir tidak ada.

Komunikasi sangat penting dilakukan dalam organisasi, karena menyangkut penyampaian pesan antar individu dalam kelompok tentang pekerjaan yang harus dilakukan dalam organisasi. Komunikasi merupakan variabel yang tidak dapat dikesampingkan dalam usaha perusahaan meningkatkan kinerja. Komunikasi adalah sistem aliran yang menghubungkan dan kinerja antar bagian dalam organisasi sehingga menghasilkan suatu sinergi. Komunikasi yang efektif antara atasan dan bawahan sangat penting bagi keberhasilan perusahaan, dengan terjalinnya komunikasi yang baik, maka penurunan kinerja dapat dicegah. Komunikasi adalah proses penyampaian pesan atau maksud yang dilakukan melalui satu pihak atau seseorang kepada pihak atau orang lain baik dilakukan secara langsung atau melalui media. Komunikasi organisasi merupakan pengiriman dan penerimaan berbagai pesan, di dalam kelompok formal maupun informal organisasi. Beberapa peneliti telah menguji hubungan antara komunikasi dengan kinerja karyawan, antara lain Ardiansyah (2016), Sembiring (2015), dan Alan \& Sudibya (2019) menyatakan bahwa komunikasi berpengaruh signifikan terhadap kinerja karyawan.

Disiplin kerja termasuk hal yang paling penting di perusahaan, karena tanpa disiplin yang baik tidak mungkin tercipta proses kerja yang baik. Suprayitno (2016) menyatakan bahwa disiplin kerja yang baik adalah disiplin kerja yang didorong oleh kesadaran diri terhadap tugas, dan tanggung jawab masing-masing karyawan tanpa adanya paksaan dari pimpinan. Salah satu syarat agar disiplin dapat ditumbuhkan dalam lingkungan kerja ialah, adanya pembagian kerja yang tuntas sampai kepada karyawan yang paling bawah, sehingga setiap orang tahu dengan sadar apa tugasnya, bagaimana melakukannya, kapan pekerjaan dimulai 
dan selesai, seperti apa hasil kerja yang disyaratkan, dan kepada siapa mempertanggung jawabkan hasil pekerjaan itu.

Kompensasi yaitu segala sesuatu yang diterima para karyawan sebagai balas jasa untuk hasil kerja mereka. Kompensasi diklasifikasikan menjadi dua yaitu kompensasi langsung seperti gaji dan upah serta insentif dan kompensasi tidak langsung seperti kesejahteraan dan pelayanan karyawan. Karyawan merasa kurang nyaman, kurangnya perawatan kerja, dan kurangnya gaji dan insentif yang pada akhirnya menyebabkan kinerja karyawan pun menurun. Beberapa dari permasalahan ini mengakibatkan pekerja menurunkan kinerjanya yang menyebabkan terjadinya peningkatan terhadap tingkat absensi pekerja datang terlambat, maupun pulang lebih awal. Pemberian kompensasi bertujuan untuk memotivasi karyawan agar lebih giat dan disiplin saat bekerja, dapat menciptakan kesadaran bersama antar karyawan, mampu mengerjakan segala sesuatu yang dibutuhkan perusahaan, mampu menggerakkan dan mengarahkan karyawan kepada perilaku untuk mencapai hasil kerja yang baik dan meningkatkan kinerjanya. Dengan terpenuhinya kompensasi akan mampu meningkatkan kinerja karyawannya.

Penelitian ini dilakukan pada Warung Mak Beng Cabang Ubud yang merupakan perusahaan yang bergerak di bidang kuliner yang sangat populer di pulau Bali yang berdiri sejak tahun 1941. Berdasarkan wawancara yang dilakukan kepada Manager Warung Mak Beng Cabang Ubud menghadapi permasalahan rendahnya kinerja karyawan dalam memiliki inisiatif yang berguna membantu penyelesaian pekerjaan yang baik, ketelitian dalam bekerja, mematuhi peraturan perusahaan, mengutamakan kejujuran dalam melakukan pekerjaan, dan memberikan gagasan yang inovatif untuk kemajuan perusahaan. Rendahnya kinerja karyawan dapat dilihat pada Tabel 1.

Tabel 1.

Data Karyawan Mengenai Kinerja Warung Mak Beng Cabang Ubud

\begin{tabular}{|c|c|c|c|c|c|c|c|c|c|c|c|}
\hline \multirow{2}{*}{ Pernyataan } & \multicolumn{10}{|c|}{ Karyawan } & \multirow{2}{*}{ Total } \\
\hline & 1 & 2 & 3 & 4 & 5 & 6 & 7 & 8 & 9 & 10 & \\
\hline $\begin{array}{l}\text { Memiliki inisiatif } \\
\text { yang membantu } \\
\text { penyelesaian } \\
\text { pekerjaan yang } \\
\text { lebih baik }\end{array}$ & TS & $\mathrm{S}$ & $\mathrm{CS}$ & $\mathrm{S}$ & CS & $\mathrm{CS}$ & $\mathrm{S}$ & $\mathrm{S}$ & S & $\mathrm{CS}$ & $\begin{array}{l}\text { TS : } 1 \\
\text { CS :4 } \\
\text { S : } 5\end{array}$ \\
\hline $\begin{array}{l}\text { Bekerja penuh } \\
\text { ketelitian } \\
\text { untukmenghindari } \\
\text { kesalahan }\end{array}$ & $\mathrm{S}$ & CS & S & CS & TS & $\mathrm{S}$ & CS & CS & CS & $\mathrm{S}$ & $\begin{array}{l}\text { TS : } 1 \\
\text { CS :5 } \\
S: 4\end{array}$ \\
\hline $\begin{array}{l}\text { Selalu mematuhi } \\
\text { perintah atasan }\end{array}$ & $\mathrm{S}$ & $\mathrm{S}$ & $\mathrm{S}$ & SS & TS & CS & CS & SS & $\mathrm{S}$ & $\mathrm{S}$ & $\begin{array}{c}\text { TS }: 1 \\
\text { CS }: 2 \\
\text { S : } 5 \\
\text { SS : } 2\end{array}$ \\
\hline
\end{tabular}


Lanjutan Tabel 1.

\begin{tabular}{|c|c|c|c|c|c|c|c|c|c|c|c|}
\hline \multirow{2}{*}{ Pernyataan } & \multicolumn{10}{|c|}{ Karyawan } & \multirow{2}{*}{ Total } \\
\hline & 1 & 2 & 3 & 4 & 5 & 6 & 7 & 8 & 9 & 10 & \\
\hline $\begin{array}{l}\text { Mengutamakan } \\
\text { kejujuran dalam } \\
\text { setiap pekerjaan } \\
\text { yang dilakukan }\end{array}$ & CS & TS & CS & TS & CS & $\mathrm{CS}$ & $\mathrm{S}$ & $\mathrm{S}$ & S & CS & $\begin{array}{l}\text { TS }: 2 \\
\text { CS :5 } \\
\text { S : } 3\end{array}$ \\
\hline $\begin{array}{l}\text { Memberikan } \\
\text { gagasan yang } \\
\text { inovatif untuk } \\
\text { kemajuan } \\
\text { perusahaan }\end{array}$ & TS & S & $\mathrm{CS}$ & $\mathrm{CS}$ & CS & $\mathrm{CS}$ & S & SS & CS & $\mathrm{CS}$ & $\begin{array}{l}\text { TS : } 1 \\
\text { CS : } 6 \\
\text { S : } 2 \\
\text { SS : } 1\end{array}$ \\
\hline
\end{tabular}

Sumber: Manager Warung Mak Beng Cabang Ubud, 2019

Pada Tabel 1. dapat dilihat bahwa karyawan kurang dalam menjalankan suatu tugas sehingga menyebabkan penurunan pada kinerja karyawan. Dapat dilihat dari masing-masing pernyataan karyawan dominan yang menjawab CS/cukup setuju ini menjelaskan bahwa kinerja pada Warung Mak Beng Cabang Ubud belum optimal Tentu ini akan berpengaruh pada kinerja karyawan itu sendiri dan mempu merugikan perusahaan.

Berdasarkan wawancara awal yang telah dilakukan ke 5 orang karyawan dibidang Waiter, Bar, Cook, Cashier, dan Steward pada Warung Mak Beng Cabang Ubud memang benar terdapat masalah - masalah yang dialami karyawan dalam menjalankan pekerjaannya sehingga mempengaruhi kinerja, seperti dalam mengemukakan pendapat karyawan takut pendapatnya tidak diterima oleh atasan, adanya komunikasi yang kurang baik antar sesama rekan kerja sehingga menyebabkan salahpahaman dalam penyampaian informasi, terdapat karyawan Warung Mak Beng Cabang Ubud yang terlambat masuk kerja karena alasan tertentu dan tidak memberi kabar kepada atasan, sesama rekan kerja tidak saling membantu karena mengganggap karyawan lain dapat melakukan semua tugas yang sudah diberikan, terdapat karyawan Warung Mak Beng Cabang Ubud yang kurang teliti dalam melaksanakan tugas karena dalam melaksanakan tugas karyawan melakukan diskusi, dan kurangnya semangat untuk bekerja karena pendapatan yang diterima tidak ada perubahan. Berdasarkan uraian tersebut, maka tujuan penelitian ini adalah untuk menguji bagaimana pengaruh komunikasi, disiplin kerja, dan kompensasi terhadap kinerja karyawan.

Penelitian ini menggunakan Teori Pertukaran Sosial yang dikemukakan oleh Blau. Blau mengasumsikan bahwa hubungan antara karyawan dengan organisasi atau perusahaan merupakan suatu bentuk pertukaran sosial. Teori pertukaran sosial merupakan pandangan karyawan ketika mereka telah diperlakukan dengan baik oleh organisasi, mereka akan cenderung melakukan balas budi dengan berperilaku dan berpartisipasi lebih dalam orgaisasi (Kimani et al., 2017). Pertukaran sosial dapat terjadi ketika karyawan dan organisasi dapat memberikan suatu hal yang didasari pada kepercayaan. Karyawan akan mengembangkan tingkat dukungan yang kuat untuk organisasi atau pemimpin, dengan perilaku kerja yang efektif seperti kinerja yang lebih baik. 
Komunikasi yang baik dan efektif dapat membuat kinerja karyawannya menjadi lebih baik, karena pada dasarnya sebagai sumber daya manusia yang membutuhkan sesuau untuk dapat memacu keinginan mereka untuk dapat bekerja dengan giat sehingga mereka mampu meningkatkan kreativitas dan semangat kerja sesuai dengan batas kemampuan masing-masing (Srimiatun \& Prihatinta, 2017). Penelitian yang dilakukan Nabi et al. (2017) menyatakan bahwa komunikasi memiliki dampak besar pada kinerja karyawan. Menurut Atambo \& Momanyi (2016) komunikasi sangat penting dalam meningkatkan kinerja karyawan, dengan adanya komunikasi akan memudahkan seseorang untuk saling berbagi pendapat. Purba (2018) menyatakan bahwa komunikasi dapat digunakan sebagai kriteria utama untuk menentukan kinerja karyawan dalam suatu organisasi.

Rokhmawati (2018) menyebutkan komunikasi dalam perusahaan memiliki pengaruh signifikan terhadap kinerja karyawan. Nebo et al. (2015) juga mengemukakan adanya hubungan signifikan antara komunikasi yang efektif dengan kinerja karyawan. Hasil yang sama juga dikemukakan oleh Puryatini. \& Sariyathi (2017) yang menjelaskan komunikasi berpengaruh positif terhadap kinerja karyawan. Penelitian yang ditemukan oleh Lakoy (2015) dan Kemby et al. (2017) menunjukan hasil yang serupa, dimana komunikasi berpengaruh positif signifikan terhadap kinerja karyawan. Berdasarkan pemahaman tersebut dapat disusun suatu hipotesis yang menjelaskan hubungan antara komunikasi dengan kinerja karyawan sebagai berikut.

$\mathrm{H}_{1}$ : Komunikasi berpengaruh positif dan signifikan terhadap kinerja karyawan

Penelitian Apalia (2017) menemukan bahwa disiplin kerja menyebabkan peningkatan kinerja karyawan. Menurut Kurniawan \& Heryanto (2019) disiplin untuk karyawan sangatlah penting karena tindakan dan kegiatan yang dilakukan dapat mempengaruhi kinerja karyawan menjadi lebih baik atau buruk. Hadian (2018) memberikan pendapat kinerja karyawan dipengaruhi oleh disiplin kerja. Dengan memiliki disiplin yang tinggi akan meningkatkan kinerja yang baik sehingga mempermudah dalam tercapainya tujuan perusahaan. Novita (2015) menemukan dalam penelitiannya bahwa disiplin kerja memberikan pengaruh positif terhadap kinerja karyawan. Menurut Mendropa (2019) menjelaskan bahwa disiplin kerja merupakan variabel yang paling dominan mempengaruhi kinerja karyawan. Hasil penelitian yang dilakukan Gabriel et al. (2015), Hikmah \& Hemmy (2018) dan Angelina (2015) menyatakan bahwa disiplin kerja mempengaruhi kinerja karyawan. Berdasarkan pemahaman tersebut dapat disusun suatu hipotesis yang menjelaskan hubungan antara disiplin kerja dengan kinerja karyawan sebagai berikut.

$\mathrm{H}_{2}$ : Disiplin kerja berpengaruh positif dan signifikan terhadap kinerja karyawan

Penelitian Menurut Ramli (2019) kompensasi bagi karyawan sebagai faktor utama yang harus diperhitungkan ini terbukti memiliki pengaruh positif dan signifikan terhadap kinerja karyawan, karena kompensasi yang tinggi akan membuat kinerja karyawan akan meningkat secara langsung. Kinerja karyawan hanya dapat meningkat jika ada kompensasi yang mendukung sebagai hasil kerja. Untuk meningkatkan tingkat kinerja, perusahaan harus merencanakan strategi yang efektif untuk karyawan sehingga tidak terjadinya ketimpangan gaji. Njoroge 
\& Josephat (2015) menunjukkan korelasi positif antara kompensasi dan kinerja karyawan.

Menurut Darma \& Supriyanto (2017) kompensasi dalam bentuk gaji, upah, bonus, fasilitas, program perjalanan, dan tunjangan hari libur secara langsung memiliki efek positif pada kinerja karyawan. Kimani et al. (2017) mengemukakan kenaikan gaji bulanan telah mengubah sikap karyawan yang pada akhirnya meningkatkan kinerja mereka. Dengan hal tersebut menyebabkan karyawan merasa senang atas apa yang mereka kerjakan lebih dihargai. Hasil penelitian Bharata (2016), dan Onuorah et al. (2019) menunjukan hasil yang serupa dimana kompensasi berpengaruh positif dan signifikan terhadap kinerja karyawan. Berdasarkan pemahaman tersebut dapat disusun suatu hipotesis yang menjelaskan hubungan antara kompensasi dengan kinerja karyawan sebagai berikut.

$\mathrm{H}_{3}$ : Kompensasi berpengaruh positif dan signifikan terhadap kinerja karyawan Gambar 1 .

Berdasarkan perumusan hipotesis, kerangka konseptual dapat dilihat pada

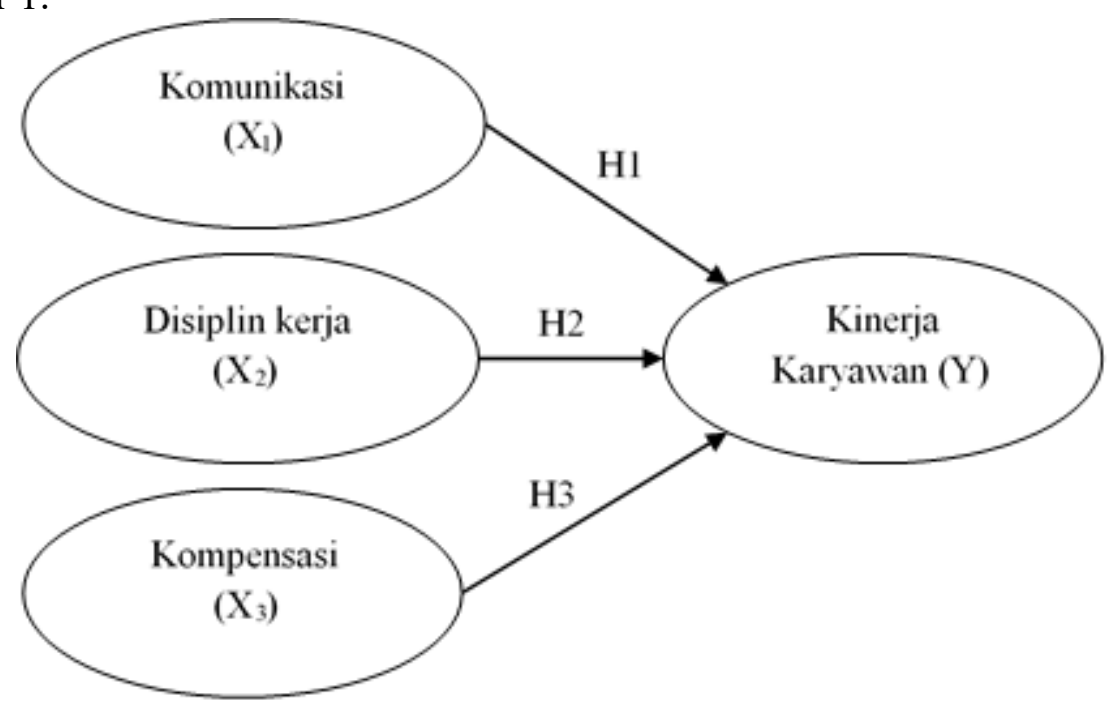

Gambar 1. Kerangka Konseptual Penelitian

\section{METODE PENELITIAN}

Pendekatan yang akan digunakan untuk meneliti sumber masalah adalah pendekatan kuantitatif yang bersifat asosiatif, penelitian yang bertujuan untuk mengetahui antara dua variabel atau lebih. Hal ini dikarenakan terdapat hubungan kausal (sebab-akibat) Jadi, disini ada variabel bebas dan variabel terikat. Hal ini berarti penelitian berfokus pada pengaruh komunikasi, disiplin kerja dan kompensasi sebagai variabel bebas terhadap kinerja karyawan sebagai variabel terikat. Lokasi penelitian adalah Warung Mak Beng yang beralamat di Jalan Cok Rai Pudak Banjar Teges Kawan Pliatan, Ubud, Gianyar. Obyek dari penelitian ini adalah komunikasi, disiplin kerja, kompensasi dan kinerja karyawan. Variabel bebas dalam penelitian ini adalah Komunikasi $\left(\mathrm{X}_{1}\right)$ Disiplin Kerja $\left(\mathrm{X}_{2}\right)$ dan Kompensasi $\left(\mathrm{X}_{3}\right)$. Variabel terikat dalam penelitian ini adalah Kinerja (Y). 
Populasi dalam penelitian ini adalah semua karyawan Warung Mak Beng Cabang Ubud yang berjumlah 40 orang. Metode penentuan sampel dilakukan dengan cara sampling jenuh, dimana semua anggota populasi digunakan sebagai sampel. Metode pengumpulan data menggunakan wawancara yaitu pengumpulan data tanya jawab secara langsung dengan pihak perusahaan mengenai kelangsungan operasional dan kuesioner yaitu metode pengumpulan data dengan menggunakan daftar pertanyaan yang disebarkan kepada responden terkait dengan variabel komunikasi, disiplin kerja, kompensasi dan kinerja.

\section{HASIL DAN PEMBAHASAN}

Data karakteristik responden adalah data responden yang dikumpulkan untuk mengetahui profil responden penelitian. Berdasarkan hasil penelitian yang dilakukan terhadap karyawan Di Warung Mak Beng dapat dijelaskan karakteristik respondennya meliputi usia. jenis kelamin, pendidikan terakhir, dan masa kerja yang dijelaskan pada Tabel 2.

Tabel 2.

Karakteristik Responden

\begin{tabular}{|c|c|c|c|}
\hline Kriteria & Klasifikasi & $\begin{array}{l}\text { Jumlah } \\
\text { (orang) }\end{array}$ & $\begin{array}{c}\text { Persentase } \\
(\%)\end{array}$ \\
\hline \multirow{4}{*}{ Usia } & $19-24$ Tahun & 19 & 47,5 \\
\hline & 25 - 29 Tahun & 6 & 15,0 \\
\hline & $30-35$ Tahun & 9 & 22,5 \\
\hline & $>35$ Tahun & 6 & 15,0 \\
\hline \multirow{3}{*}{ Jenis kelamin } & Jumlah & 40 & 100 \\
\hline & Laki-laki & 12 & 30,0 \\
\hline & Perempuan & 28 & 70,0 \\
\hline \multirow{5}{*}{$\begin{array}{l}\text { Pendidikan } \\
\text { terakhir }\end{array}$} & Jumlah & 40 & 100 \\
\hline & SMP & 2 & 5,0 \\
\hline & SMA/SMK & 20 & 50,0 \\
\hline & Diploma & 10 & 25,0 \\
\hline & S1 & 8 & 20,0 \\
\hline \multirow{5}{*}{ Masa kerja } & Jumlah & 40 & 100 \\
\hline & $1-3$ Tahun & 8 & 20,0 \\
\hline & $3-5$ Tahun & 20 & 50,0 \\
\hline & $>5$ Tahun & 12 & 30,0 \\
\hline & Jumlah & 40 & 100 \\
\hline
\end{tabular}

Sumber: Data primer diolah, 2019

Tabel 2. memperlihatkan karakteristik responden dimana usia sebagian besar karyawan adalah 19 sampai 24 tahun dengan persentase 47,5 persen atau sebanyak 19 orang karena Warung Mak Beng memerlukan tenaga ekstra dalam bekerja terutama di waitress/waiter memerlukan karyawan dengan usia muda berpenampilan menarik. Jenis Kelamin reponden dimana karyawan perempuan lebih dominan karena perusahaan ini para pekerja sebagian besar berjenis kelamin perempuan dengan keseluruhan persentase 70,0 persen atau sebanyak 28 orang dan sisanya sebesar 30 persen atau 12 orang berjenis kelamin laki - laki, hal ini dikarenakan perempuan lebih teliti dalam bekerja dan lebih cepat merespon dalam 
hal pekerjaan. Untuk posisi laki - laki lebih mendominasi pada bagian bar dan security.

Pendidikan terakhir responden lulusan SMP dengan presentase 5,0 persen atau 2 orang menduduki posisi cook karena mereka sudah sudah lebih lama bekerja di Warung Mak Beng sehingga mengerti seberapa takaran untuk resep. Lulusan SMA/SMK dengan persentase 50,0 persen atau 20 orang. Banyaknya lulusan SMA/SMK yang dipekerjakan karena pada posisi seperti waitress/waiter, prepare, steward, dan security tidak memerlukan pendidikan yang tinggi melainkan keinginan untuk belajar. Lulusan Diploma sebesar 25,0 persen atau 10 orang ditempatkan pada posisi bar dan cook sedangkan lulusan S1 sebesar 20,0 persen atau 8 orang menduduki posisi manager dan cashier. Karyawan dengan masa kerja 3 - 5 tahun lebih mendominasi bila dibandingkan dengan yang bekerja 1 - 3 tahun maupun diatas 5 tahun karena dalam beberapa posisi memerlukan karyawan yang masih tergolong muda. Tabel 3 menyajikan hasil uji validitas intrumen penelitian.

Tabel 3.

Rekapitulasi Hasil Uji Validitas Instrumen Penelitian

\begin{tabular}{|c|c|c|c|}
\hline Variabel & Indikator & R hitung & R tabel \\
\hline \multirow{9}{*}{ Kinerja Karyawan (Y) } & $Y_{.1}$ & 0,866 & 0,30 \\
\hline & $\mathrm{Y} .2$ & 0,815 & 0,30 \\
\hline & $Y_{.3}$ & 0,876 & 0,30 \\
\hline & $Y_{.4}$ & 0,910 & 0,30 \\
\hline & Y.5 & 0,895 & 0,30 \\
\hline & Y.6 & 0,885 & 0,30 \\
\hline & $Y_{.7}$ & 0,885 & 0,30 \\
\hline & Y.8 & 0,884 & 0,30 \\
\hline & Y.9 & 0,874 & 0,30 \\
\hline \multirow{4}{*}{ Komunikasi $\left(\mathrm{X}_{1}\right)$} & $\mathrm{X}_{1.1}$ & 0,914 & 0,30 \\
\hline & $\mathrm{X}_{1.2}$ & 0,867 & 0,30 \\
\hline & $\mathrm{X}_{1.3}$ & 0,895 & 0,30 \\
\hline & $\mathrm{X}_{1.4}$ & 0,901 & 0,30 \\
\hline \multirow{4}{*}{ Disiplin Kerja $\left(\mathrm{X}_{2}\right)$} & $\mathrm{X}_{2.1}$ & 0,864 & 0,30 \\
\hline & $\mathrm{X}_{2.2}$ & 0,937 & 0,30 \\
\hline & $\mathrm{X}_{2.3}$ & 0,895 & 0,30 \\
\hline & $\mathrm{X}_{2.4}$ & 0,872 & 0,30 \\
\hline \multirow{4}{*}{ Kompensasi $\left(\mathrm{X}_{3}\right)$} & $X_{3.1}$ & 0,899 & 0,30 \\
\hline & $X_{3.2}$ & 0,914 & 0,30 \\
\hline & $\mathrm{X}_{3.3}$ & 0,844 & 0,30 \\
\hline & $\mathrm{X}_{3.4}$ & 0,947 & 0,30 \\
\hline
\end{tabular}

Sumber: Data primer diolah, 2019

Hasil uji validitas pada Tabel 3. menunjukkan bahwa seluruh instrumen penelitian yang digunakan untuk mengukur variabel komunikasi, disiplin kerja, kompensasi, dan kinerja karyawan memiliki nilai koefisien korelasi dengan skor total seluruh item pernyataan lebih besar dari 0,30. Hal ini menunjukkan bahwa butir-butir pernyataan dalam instrument penelitian tersebut valid dan layak digunakan sebagai instrument penelitian. Tabel 4 menyajikan hasil uji reliabilitas instrumen penelitian. 
Tabel 4.

Rekapitulasi Hasil Uji Reliabilitas Instrumen Penelitian

\begin{tabular}{clc}
\hline No. & \multicolumn{1}{c}{ Variabel } & Cronbach's Alpha \\
\hline 1 & Kinerja Karyawan $(\mathrm{Y})$ & 0,962 \\
2 & Komunikasi $\left(\mathrm{X}_{1}\right)$ & 0,915 \\
3 & Disiplin Kerja $\left(\mathrm{X}_{2}\right)$ & 0,911 \\
4 & Kompensasi $\left(\mathrm{X}_{3}\right)$ & 0,918 \\
\hline
\end{tabular}

Hasil uji reliabilitas yang disajikan dalam Tabel 4. menunjukkan bahwa seluruh instrumen penelitian memiliki koefisien Cronbach's Alpha lebih dari 0,60. Jadi dapat dinyatakan bahwa seluruh variabel telah memenuhi syarat reliabilitas atau kehandalan sehingga dapat digunakan untuk melakukan penelitian.

Variabel Kinerja Karyawan dalam penelitian ini merupakan variabel terikat yang diukur dengan menggunakan 9 pernyataan yang berhubungan dengan Kinerja Karyawan. Secara rinci hasil penelitian mengenai jawaban responden terhadap variabel Kinerja Karyawan dapat dilihat pada Tabel 5.

Tabel 5.

Deskripsi Jawaban Responden Terhadap Kinerja Karyawan

\begin{tabular}{|c|c|c|c|c|c|c|c|c|}
\hline \multirow{2}{*}{ No } & \multirow{2}{*}{ Pernyataan } & \multicolumn{5}{|c|}{ Jawaban } & \multirow{2}{*}{ Rata-Rata } & \multirow{2}{*}{ Kriteria } \\
\hline & & STS & TS & $\mathrm{CS}$ & $\mathbf{S}$ & SS & & \\
\hline 1 & $\begin{array}{l}\text { Dapat menyelesaikan tugas } \\
\text { sesuai dengan tanggung jawab }\end{array}$ & 0 & 1 & 13 & 14 & 12 & 3,92 & Baik \\
\hline 2 & $\begin{array}{l}\text { Menyelesaikan pekerjaan } \\
\text { dengan mengutamakan hasil } \\
\text { pekerjaan yang bermutu sesuai } \\
\text { dengan peraturan yang ada }\end{array}$ & 0 & 0 & 12 & 17 & 11 & 3,98 & Baik \\
\hline 3 & $\begin{array}{l}\text { Mampu menyelesaikan tugas } \\
\text { sesuai dengan waktu yang } \\
\text { ditentukan. }\end{array}$ & 0 & 1 & 11 & 20 & 8 & 3,87 & Baik \\
\hline 4 & $\begin{array}{l}\text { Hadir tepat waktu dengan } \\
\text { waktu yang sudah ditetapkan } \\
\text { perusahaan. }\end{array}$ & 0 & 1 & 14 & 14 & 11 & 3,88 & Baik \\
\hline 5 & $\begin{array}{l}\text { Memiliki inisiatif yang } \\
\text { berguna membantu } \\
\text { penyelesaian pekerjaan yang } \\
\text { lebih baik. }\end{array}$ & 0 & 2 & 11 & 20 & 7 & 3,80 & Baik \\
\hline 6 & $\begin{array}{l}\text { Bekerja penuh ketelitian untuk } \\
\text { menghindari kesalahan. }\end{array}$ & 0 & 2 & 14 & 17 & 7 & 3,72 & Baik \\
\hline 7 & $\begin{array}{l}\text { Selalu mematuhi perintah dari } \\
\text { atasan. }\end{array}$ & 0 & 3 & 10 & 20 & 7 & 3,78 & Baik \\
\hline 8 & $\begin{array}{l}\text { Mengutamakan kejujuran } \\
\text { dalam setiap pekerjaan yang } \\
\text { dilakukan. }\end{array}$ & 0 & 7 & 9 & 21 & 3 & 3,50 & Baik \\
\hline 9 & $\begin{array}{l}\text { Memberikan gagasan yang } \\
\text { inovatif untuk kemajuan } \\
\text { perusahaan. }\end{array}$ & 0 & 3 & 15 & 12 & 10 & 3,73 & Baik \\
\hline & Rata-rata keseluruhan v & bel $\mathbf{K}$ & & & & & 3,80 & Baik \\
\hline
\end{tabular}


Tabel 5. menunjukan bahwa rata-rata keseluruhan deskripsi jawaban responden pada variabel kinerja karyawan yaitu sebesar 3,80 yang berada dalam kriteria baik. Tetapi rata - rata jawaban responden masih ada yang dibawah ratarata keseluruhan sehingga dapat dikatakan kinerja karyawan belum optimal. Interpretasi dengan nilai diatas rata - rata dengan penyataan karyawan dapat menyelesaikan pekerjaan dengan mengutamakan hasil pekerjaan yang bermutu sesuai dengan peraturan yang ada dengan skor rata - rata 3,98 sehingga dapat dikatakan para karyawan Warung Mak Beng Cabang Ubud menganggap bahwa lemah kuatnya kinerja sangat tergantung dari kualitas kerja yang telah dilakukan yaitu seberapa baik penyelesaiannya. Sementara itu, indikator dengan nilai terendah ditunjukan pada pernyataan mengutamakan kejujuran dalam setiap pekerjaan yang dilakukan karyawan dengan skor rata - rata 3,50. Dapat dikatakan kurangnya rasa kejujuran karyawan dalam melaksanakan pekerjaan sehingga menyebabkan karyawan tidak maksimal dalam melakukan pekerjaannya. Hasil ini dapat berarti para karyawan Warung Mak Beng Cabang Ubud cenderung tidak peduli mengenai kejujuran dalam melaksanakan pekerjaannya.

Variabel Komunikasi dalam penelitian ini merupakan variabel bebas yang diukur dengan menggunakan 4 pernyataan yang berhubungan dengan Komunikasi. Secara rinci hasil penelitian mengenai jawaban responden terhadap variabel Komunikasi dapat dilihat pada Tabel 6.

Tabel 6.

Deskripsi Jawaban Responden Terhadap Komunikasi

\begin{tabular}{|c|c|c|c|c|c|c|c|c|}
\hline \multirow{2}{*}{ No } & \multirow{2}{*}{ Pernyataan } & \multicolumn{5}{|c|}{ Jawaban } & \multirow{2}{*}{ Rata-Rata } & \multirow{2}{*}{ Kriteria } \\
\hline & & STS & TS & CS & $\mathbf{S}$ & SS & & \\
\hline 1 & $\begin{array}{l}\text { Memahami tugas-tugas yang } \\
\text { diberikan saat diskusi mengenai } \\
\text { pekerjaan dengan baik. }\end{array}$ & 0 & 1 & 12 & 18 & 9 & 3,87 & Baik \\
\hline 2 & $\begin{array}{l}\text { Menindaklanjuti intruksi yang } \\
\text { sudah diberikan oleh atasan ke } \\
\text { dalam pekerjaan. }\end{array}$ & 0 & 3 & 12 & 21 & 4 & 3,65 & Baik \\
\hline 3 & $\begin{array}{l}\text { Berkoordinasi dengan sesama } \\
\text { rekan kerja dalam memecahkan } \\
\text { masalah pekerjaan }\end{array}$ & 0 & 5 & 21 & 8 & 6 & 3,38 & $\begin{array}{l}\text { Cukup } \\
\text { Baik }\end{array}$ \\
\hline 4 & $\begin{array}{l}\text { Tegur sapa sesama rekan kerja } \\
\text { terjalin dengan baik. }\end{array}$ & 0 & 5 & 20 & 13 & 2 & 3,30 & $\begin{array}{l}\text { Cukup } \\
\text { Baik }\end{array}$ \\
\hline \multicolumn{7}{|c|}{ Rata-rata keseluruhan variabel Komunikasi } & 3,55 & Baik \\
\hline
\end{tabular}

Sumber: Data Primer Diolah, 2019

Tabel 6. menunjukan bahwa Komunikasi Warung Mak Beng Cabang Ubud tergolong baik. Hal itu dapat dilihat dari nilai rata - rata skor sebesar 3,55. Indikator komunikasi dengan nilai yang sangat baik dapat dijelaskan oleh pernyataan dimana karyawan memahami tugas-tugas yang diberikan saat diskusi mengenai pekerjaan dengan skor rata - rata 3,87 hasil ini dapat berarti bahwa dengan menggunakan komunikasi yang baik dan jelas dapat memudahkan karyawan dalam memahami tugas yang diberikan. Sementara itu, indikator terendah dapat dijelaskan oleh pernyataan tegur sapa sesama rekan kerja terjalin dengan baik dengan skor rata - rata sebesar 3,30 hal tersebut dapat berarti 
karyawan merasa komunikasi antara karyawan satu dengan karyawan lain tidak sependapat sehingga menyebabkan karyawan merasa tidak leluasa untuk mengemukakan pendapat kepada sesama pekerja.

Variabel Disiplin Kerja dalam penelitian ini merupakan variabel bebas yang diukur dengan menggunakan 4 pernyataan yang berhubungan dengan Disiplin Kerja. Secara rinci hasil penelitian mengenai jawaban responden terhadap variabel Disiplin Kerja dapat dilihat pada Tabel 7.

Tabel 7.

Deskripsi Jawaban Responden Terhadap Disiplin Kerja

\begin{tabular}{|c|c|c|c|c|c|c|c|c|}
\hline \multirow{2}{*}{ No } & \multirow{2}{*}{ Pernyataan } & \multicolumn{5}{|c|}{ Jawaban } & \multirow{2}{*}{ Rata-Rata } & \multirow{2}{*}{ Kriteria } \\
\hline & & STS & TS & CS & $\mathbf{S}$ & SS & & \\
\hline 1 & $\begin{array}{l}\text { Jarang melanggar peraturan } \\
\text { mengenai jadwal kerja. }\end{array}$ & 0 & 0 & 8 & 18 & 14 & 4,15 & Tinggi \\
\hline 2 & $\begin{array}{l}\text { Menguasai cara penggunaan } \\
\text { peralatan kerja. } \\
\text { Dapat mengerjakan tugas }\end{array}$ & 0 & 0 & 4 & 23 & 13 & 4,23 & $\begin{array}{l}\text { Sangat } \\
\text { Tinggi }\end{array}$ \\
\hline 3 & $\begin{array}{l}\text { sesuai dengan instruksi atasan } \\
\text { mengenai pekerjaan. }\end{array}$ & 0 & 1 & 8 & 21 & 10 & 4,00 & Tinggi \\
\hline 4 & $\begin{array}{l}\text { Taat dalam berpakaian sesuai } \\
\text { dengan aturan yang berlaku } \\
\text { dalam perusahaan. }\end{array}$ & 0 & 1 & 5 & 25 & 9 & 4,05 & Tinggi \\
\hline \multicolumn{7}{|c|}{ Rata-rata keseluruhan variabel Disiplin Kerja } & 4,11 & Tinggi \\
\hline
\end{tabular}

Sumber: Data Primer Diolah, 2019

Tabel 7. menunjukan bahwa Disiplin Kerja Warung Mak Beng Cabang Ubud tergolong tinggi. Hal itu dapat dilihat dari nilai rata - rata skor sebesar 4,11. Indikator disiplin kerja dengan nilai yang sangat tinggi dapat dijelaskan oleh pernyataan dimana karyawan menguasai cara penggunaan peralatan kerja dengan skor rata - rata 4,23 dengan kategori sangat tinggi. Hasil ini dapat berarti bahwa karyawan mematuhi aturan menggunakan peralatan dengan baik dan benar. Sementara itu, indikator dengan nilai terendah terdapat pada penyataan dimana karyawan mengerjakan tugas sesuai dengan instruksi atasan mengenai pekerjaan dengan skor rata - rata 4,00 hal ini menunjukan rendahnya disiplin karyawan mengenai pelaksanaan tugas dengan aturan. Masih ada karyawan yang belum menyelesaikan tugas sesuai dengan aturan. Sehingga dalam penyelesaian tugas adanya keterlambatan karyawan untuk menyelesaikannya yang menyebabkan kinerja perusahaan menjadi relatif rendah.

Variabel Kompensasi dalam penelitian ini merupakan variabel bebas yang diukur dengan menggunakan 4 pernyataan yang berhubungan dengan Kompensasi. Secara rinci hasil penelitian mengenai jawaban responden terhadap variabel Kompensasi dapat dilihat pada Tabel 8. 
Tabel 8.

Deskripsi Jawaban Responden Terhadap Kompensasi

\begin{tabular}{clcccccccc}
\hline \multirow{2}{*}{ No } & \multicolumn{7}{c}{ Pernyataan } & \multicolumn{7}{c}{ Jawaban } & Rata-Rata & Kriteria \\
\cline { 2 - 5 } & STS & TS & CS & S & SS & Baik \\
\hline 1 & $\begin{array}{l}\text { Menerima gaji sesuai dengan } \\
\text { beban kerja yang diberikan } \\
\text { perusahaan }\end{array}$ & 0 & 2 & 17 & 9 & 12 & 3,77 & Baik \\
2 & $\begin{array}{l}\text { Menerima bonus sesuai } \\
\text { dengan ketentuan perusahaan }\end{array}$ & 0 & 3 & 6 & 19 & 12 & 4,00 & Baik \\
3 & $\begin{array}{l}\text { Menerima tunjangan hari raya } \\
\text { dari perusahaan }\end{array}$ & 0 & 7 & 3 & 12 & 18 & 4,03 & Baik \\
\hline $\begin{array}{l}\text { Menerima sembako disetiap } \\
\text { tahunnya dari perusahaan }\end{array}$ & 0 & 8 & 13 & 8 & 11 & 3,55 & Baik \\
\hline \multicolumn{1}{c}{ Rata-rata keseluruhan variabel Kompensasi } \\
\hline Sumber: Data Primer Diolah, 2019
\end{tabular}

Tabel 8. dapat diketahui bahwa Kompensasi Warung Mak Beng Cabang Ubud tergolong baik namun belum optimal karena masih ada hasil rata - rata jawab dibawah rata - rata keseluruhan. Hal itu dapat dilihat dari nilai rata - rata skor sebesar 3,84. Indikator kompensasi dengan nilai yang sangat baik dapat dijelaskan oleh pernyataan dimana karyawan menerima tunjangan kesehatan beserta tunjangan hari raya dari perusahaan dengan skor rata - rata 4,03 hasil ini berarti tingginya kinerja dapat diperoleh melalui adanya tunjangan yang menjamin. Sementara itu, indikator terendah dapat dijelaskan oleh pernyataan menerima sembako disetiap tahunnya dari perusahaan dengan skor rata - rata 3,55 ini berarti tidak adanya hal yang membuat karyawan harus lebih meningkatkan kinerja dengan demikian pemberian fasilitas untuk karyawan akan membuat kinerja karyawan menjadi meningkat. Hasil analisis regresi linier berganda dapat dilihat pada Tabel 9.

Tabel 9.

Hasil Analisis Regresi Linier Berganda

\begin{tabular}{|c|c|c|c|c|c|}
\hline \multirow[t]{2}{*}{ Model } & \multicolumn{2}{|c|}{$\begin{array}{c}\text { Unstandardized } \\
\text { Coefficients }\end{array}$} & \multirow{2}{*}{$\begin{array}{c}\begin{array}{c}\text { Standardized } \\
\text { Coefficients }\end{array} \\
\text { Beta } \\
\end{array}$} & \multirow[t]{2}{*}{$\mathbf{T}$} & \multirow[t]{2}{*}{ Sig. } \\
\hline & B & Std. Error & & & \\
\hline (Constant) &,- 046 & 3,775 & &,- 012 & 0,990 \\
\hline Komunikasi (X1) & 0,519 & 0,222 & 0,227 & 2,336 & 0,025 \\
\hline Disiplin Kerja (X2) & 0,828 & 0,297 & 0,313 & 2,786 & 0,008 \\
\hline Kompensasi (X3) & 0,864 & 0,236 & 0,480 & 3,654 & 0,001 \\
\hline \multicolumn{6}{|l|}{$\begin{array}{l}\text { Kinerja karyawan } \\
(\mathrm{Y})\end{array}$} \\
\hline$R$ Square & & & 0,792 & & \\
\hline Adjudted R Square & & & 0,778 & & \\
\hline F hitung & & & 46,602 & & \\
\hline Singnifikansi F & & & 0,000 & & \\
\hline
\end{tabular}

Sumber: Data primer diolah, 2019 
Berdasarkan Tabel 9 dapat dibuat persamaan regresi linier berganda berikut: $\mathrm{Y}=-0,046+0,519 \mathrm{X}_{1}+0,828 \mathrm{X}_{2}+0,864 \mathrm{X}_{3}$

Dengan demikan koefisien regresi dari komunikasi sebesar 0,519 berarti bahwa apabila komunikasi $\left(\mathrm{X}_{1}\right)$ meningkat dengan anggapan bahwa variabel bebas lainnya konstan, maka kinerja karyawan akan mengalami peningkatan. Koefisien regresi dari disiplin kerja sebesar 0,828 berarti bahwa apabila disiplin kerja $\left(\mathrm{X}_{2}\right)$ meningkat dengan anggapan bahwa variabel bebas lainnya konstan, maka kinerja karyawan akan mengalami peningkatan. Koefisien regresi dari kompensasi sebesar 0,864 berarti bahwa apabila kompensasi $\left(\mathrm{X}_{3}\right)$ meningkat dengan anggapan bahwa variabel bebas lainnya konstan, maka kinerja karyawan akan mengalami peningkatan. Hasil uji normalitas dapat dilihat pada Tabel 10.

Tabel 10.

Hasil Uji Normalitas

\begin{tabular}{lr}
\hline & Unstandardized Residual \\
\hline N & 40 \\
Test Statistic &, 131 \\
Asymp. Sig. (2-tailed) &, $081^{\text {c }}$ \\
\hline Sumber: Data primer diolah, 2019 &
\end{tabular}

Berdasarkan hasil analisis didapat nilai signifikansi sebesar 0,081 seperti yang diajukan oleh Tabel 10. Karena nilai signifikansi uji Kolmogorov-Smirnov lebih dari 0.05 maka dapat disimpulkan bahwa model regresi yang digunakan dalam penelitian ini terdistribusi secara normal. Hasil uji heteroskedastisitas dapat dilihat pada Tabel 11 .

Tabel 11.

Hasil Uji Heteroskedastisitas

\begin{tabular}{lcl}
\hline \multicolumn{1}{c}{ Variabel } & Signifikan & \multicolumn{1}{c}{ Keterangan } \\
\hline Komunikasi & 0,676 & Bebas Heteroskedastisitas \\
Disiplin Kerja & 0,301 & Bebas Heteroskedastisitas \\
Kompensasi & 0,474 & Bebas Heteroskedastisitas \\
\hline
\end{tabular}

Sumber: Data primer diolah, 2019

Berdasarkan Tabel 11. diatas dapat dilihat bahwa nilai signifikan untuk variabel Komunikasi sebesar 0,676 (0,676>0,05), nilai signifikan untuk variabel Disiplin Kerja sebesar 0,301 $(0,301>0,05)$, dan nilai signifikan untuk variabel Kompensasi sebesar 0,474 $(0,474>0,05)$. Semua variabel bebas memiliki nilai signifikansi lebih dari 0,05 yang berarti tidak terdapat perngaruh antara variabel bebas terhadap absolute residual. Dengan demikian, model yang dibuat tidak mengandung gejala heteroskedastisitas. Hasil uji multikolinieritas dapat dilihat pada Tabel 12. 
Tabel 12.

Hasil Uji Multikolinieritas

\begin{tabular}{cccc}
\hline Variabel & Tolerance & VIF & Keterangan \\
\hline Komunikasi & 0,602 & 1,662 & Bebas Multikolinieritas \\
Disiplin Kerja & 0,452 & 2,212 & Bebas Multikolinieritas \\
Kompensasi & 0,330 & 3,032 & Bebas Multikolinieritas \\
\hline
\end{tabular}

Sumber: Data primer diolah, 2019

Berdasarkan hasil uji pada Tabel 12. dapat diketahui bahwa nilai tolerance untuk variabel Komunikasi sebesar 0,602 $(0,602>0,1)$ dengan nilai VIF sebesar $1,662(1,662<10)$, nilai tolerance untuk variabel Disiplin kerja sebesar 0,452 $(0,452>0,1)$ dengan nilai VIF sebesar 2,212 $(2,212<10)$, dan nilai tolerance untuk variabel Kompensasi sebesar 0,330 $(0,330>0,1)$ dengan nilai VIF sebesar $3,032(3,032<10)$. Ini menunjukkan nilai tolerance untuk setiap variabel lebih dari $10 \%$ dan VIF lebih kecil dari 10 yang berarti model persamaan regresi bebas multikolinearitas.

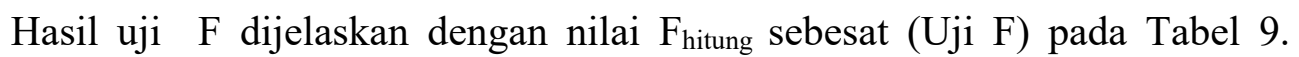
diperoleh nilai signifikansi $\mathrm{F}$ sebesar 46,602 dengan signifikansi sebesar $0,000<$ 0,05 hasil ini mempunyai arti bahwa komunikasi (X1), disiplin kerja (X2) dan kompensasi (X3) berpengaruh signifikan secara serempak atau sama - sama terhadap kinerja karyawan (Y), sehingga penelitian ini dapat dikatakan memenuhi uji kelayakan model atau model penelitian ini dinyatakan layak untuk digunakan sebagai model regresi.

Ketepatan model juga dilihat dari nilai koefisien determinansi $\left(\mathrm{R}^{2}\right)$ pada Tabel 9. dapat diamati nilai adjusted $\mathrm{R}^{2}$ sebesar 0,778 berarti 77,8 persen perubahan (naik turun) pada Kinerja Karyawan yang dipengaruhi oleh (Komunikasi, stress kerja, dan Kompensasi, sementara sisanya sejumlah 22,2\% dipengaruhi oleh faktor - faktor lain diluar penelitian ini seperti kondisi lingkungan, kesehatan, pengalaman kerja, dll.

Hasil uji t pengaruh Komunikasi terhadap Kinerja Karyawan diperoleh nilai signifikansi sebesar 0,025 dengan nilai koefisien regresi sebesar 0,519 bernilai positif. Nilai signifikansi $0,025<0,05$ mengindikasikan bahwa $\mathrm{H}_{1}$ diterima. Hasil ini mempunyai arti bahwa komunikasi berpengaruh positif dan signifikan terhadap kinerja karyawan. Hasil uji t pengaruh Disiplin Kerja terhadap Kinerja Karyawan diperoleh nilai signifikansi sebesar 0,008 dengan nilai koefisien regresi sebesar 0,828 bernilai positif. Nilai signifikansi $0,008<0,05$ mengindikasikan bahwa $\mathrm{H}_{2}$ diterima. Hasil ini mempunyai arti bahwa disiplin kerja berpengaruh positif dan signifikan terhadap kinerja karyawan. Hasil uji t pengaruh Kompensasi terhadap Kinerja Karyawan diperoleh nilai signifikansi sebesar 0,001 dengan nilai koefisien regresi sebesar 0,864 bernilai positif. Nilai signifikansi $0,001<0,05$ mengindikasikan bahwa $\mathrm{H}_{3}$ diterima. Hasil ini mempunyai arti bahwa kompensasi berpengaruh positif dan signifikan terhadap kinerja karyawan.

Berdasarkan hasil uji t pengaruh Komunikasi terhadap Kinerja Karyawan diperoleh nilai signifikansi sebesar 0,025 dengan nilai koefisien regresi sebesar 0,519 bernilai positif. Nilai signifikansi $0,025<0,05$ mengindikasikan bahwa $\mathrm{H}_{1}$ diterima. Hasil menunjukan bahwa komunikasi berpengaruh positif dan signifikan 
terhadap kinerja karyawan. Hal ini berarti jika Komunikasi semakin baik, maka kinerja karyawan semakin baik pula. Kinerja karyawan yang baik apabila karyawan mampu berkomunikasi dengan baik. Salah satunya karyawan dapat berkoordinasi dengan sesama rekan kerja dalam memecahkan masalah pekerjaan serta adanya tegur sapa yang baik dengan sesama rekan kerja. Komunikasi yang sangat baik dapat dijelaskan oleh pernyataan memahami tugas yang diberikan saat diskusi mengenai pekerjaan dan menindaklanjuti diskusi yang sudah diberikan ke dalam pekerjaan.

Hasil penelitian ini sesuai dengan penelitian sebelumnya yang menyatakan Komunikasi yang baik dan efektif dapat membuat kinerja karyawannya menjadi lebih baik, karena pada dasarnya sebagai sumber daya manusia yang membutuhkan sesuau untuk dapat memacu keinginan mereka untuk dapat bekerja dengan giat sehingga mereka mampu meningkatkan kreativitas dan semangat kerja sesuai dengan batas kemampuan masing-masing (Srimiatun \& Prihatinta, 2017). Penelitian yang dilakukan Nabi et al. (2017) menyatakan bahwa komunikasi memiliki dampak besar pada kinerja karyawan.

Menurut Atambo \& Momanyi (2016) komunikasi sangat penting dalam meningkatkan kinerja karyawan, dengan adanya komunikasi akan memudahkan seseorang untuk saling berbagi pendapat. Purba (2018) menyatakan bahwa komunikasi dapat digunakan sebagai kriteria utama untuk menentukan kinerja karyawan dalam suatu organisasi. Rokhmawati (2018) menyebutkan komunikasi dalam perusahaan memiliki pengaruh signifikan terhadap kinerja karyawan. Nebo et al. (2015) juga mengemukakan adanya hubungan signifikan antara komunikasi yang efektif dengan kinerja karyawan. Hasil yang sama juga dikemukakan oleh Puryatini. \& Sariyathi (2017) yang menjelaskan komunikasi berpengaruh positif terhadap kinerja karyawan. Penelitian yang ditemukan oleh Lakoy (2015) dan Kemby et al. (2017) menunjukan hasil yang serupa, dimana komunikasi berpengaruh positif signifikan terhadap kinerja karyawan.

Berdasarkan hasil uji t pengaruh Disiplin Kerja terhadap Kinerja Karyawan diperoleh nilai signifikansi sebesar 0,008 dengan nilai koefisien regresi sebesar 0,828 bernilai positif. Nilai signifikansi $0,008<0,05$ mengindikasikan bahwa $\mathrm{H}_{2}$ diterima. Hasil tersebut menunjukkan bahwa disiplin kerja berpengaruh positif dan signifikan terhadap kinerja karyawan. Hal ini berarti jika disiplin kerja semakin baik, maka kinerja karyawan semakin baik. Kinerja karyawan yang baik apabila karyawan memiliki disiplin kerja yang baik. Salah satunya karyawan mengerjakan tugas sesuai dengan instruksi atasan mengenai pekerjaan serta taat dalam berpakaian sesuai dengan aturan yang berlaku dalam perusahaan dengan mematuhi segala aturan yang akan akan menciptakan kinerja yang baik. Disiplin kerja yang sangat baik dapat dijelaskan oleh pernyataan menguasai cara penggunaan peralatan kerja dan jarang melanggar peraturan mengenai jadwal kerja.

Hasil penelitian ini sesuai dengan penelitian sebelumnya yang dilakukan Penelitian Apalia (2017) menemukan bahwa disiplin kerja menyebabkan peningkatan kinerja karyawan. Menurut Kurniawan \& Heryanto (2019) disiplin untuk karyawan sangatlah penting karena tindakan dan kegiatan yang dilakukan dapat mempengaruhi kinerja karyawan menjadi lebih baik atau buruk. Hadian 
(2018) memberikan pendapat kinerja karyawan dipengaruhi oleh disiplin kerja. Dengan memiliki disiplin yang tinggi akan meningkatkan kinerja yang baik sehingga mempermudah dalam tercapainya tujuan perusahaan. Novita (2015) menemukan dalam penelitiannya bahwa disiplin kerja memberikan pengaruh positif terhadap kinerja karyawan. Menurut Mendropa (2019) menjelaskan bahwa disiplin kerja merupakan variabel yang paling dominan mempengaruhi kinerja karyawan. Hasil penelitian yang dilakukan Gabriel et al. (2015), Hikmah \& Hemmy (2018) dan Angelina (2015) menyatakan bahwa disiplin kerja mempengaruhi kinerja karyawan.

Berdasarkan hasil uji t pengaruh Kompensasi terhadap Kinerja Karyawan diperoleh nilai signifikansi sebesar 0,001 dengan nilai koefisien regresi sebesar 0,864 bernilai positif. Nilai signifikansi $0,001<0,05$ mengindikasikan bahwa $\mathrm{H}_{3}$ diterima. Hasil menunjukkan bahwa kompensasi berpengaruh positif dan signifikan terhadap kinerja karyawan. Hal ini berarti jika Kompensasi semakin baik, maka kinerja karyawan semakin baik. Kinerja karyawan yang baik apabila karyawan mendapatkan kompenasasi yang baik. Salah satunya karyawan menerima gaji sesuai dengan beban kerja yang diberikan serta menerima fasilitas disetiap tahunnya dari perusahaan. Pemberian kompensasi yang sangat baik dapat dijelaskan oleh pernyataan menerima tunjangan kesehatan beserta tunjangan hari raya dan menerima bonus sesuai dengan ketentuan perusahaan. Dapat dilihat dari penilitian - penelitian terdahulu sebagai berikut.

Hasil penelitian ini sesuai dengan penelitian sebelumnya yang dilakukan Menurut Ramli (2019) kompensasi bagi karyawan sebagai faktor utama yang harus diperhitungkan ini terbukti memiliki pengaruh positif dan signifikan terhadap kinerja karyawan, karena kompensasi yang tinggi akan membuat kinerja karyawan akan meningkat secara langsung. Kinerja karyawan hanya dapat meningkat jika ada kompensasi yang mendukung sebagai hasil kerja. Untuk meningkatkan tingkat kinerja, perusahaan harus merencanakan strategi yang efektif untuk karyawan sehingga tidak terjadinya ketimpangan gaji.

Njoroge \& Josephat (2015) menunjukkan korelasi positif antara kompensasi dan kinerja karyawan. Menurut Darma \& Supriyanto (2017) "kompensasi dalam bentuk gaji, upah, bonus, fasilitas, program perjalanan, dan tunjangan hari libur secara langsung memiliki efek positif pada kinerja karyawan." Kimani et al. (2017) mengemukakan kenaikan gaji bulanan telah mengubah sikap karyawan yang pada akhirnya meningkatkan kinerja mereka. Dengan hal tersebut menyebabkan karyawan merasa senang atas apa yang mereka kerjakan lebih dihargai. Hasil penelitian Bharata (2016), dan Onuorah et al. (2019) menunjukan hasil yang serupa dimana kompensasi berpengaruh positif dan signifikan terhadap kinerja karyawan.

Berdasarkan hasil penelitian dan pemaparan diperoleh bahwa komunikasi berpengaruh positif dan signifikan terhadap kinerja karyawan. Hasil tersebut mengimplikasi bahwa kinerja karyawan dengan didukung dengan penggunaan komunikasi dengan baik dan benar dalam menjelaskan suatu informasi. Komunikasi dapat ditingkatkan melalui tegur sapa sesama rekan kerja terjalin dengan baik. 
Sedangkan hasil disiplin kerja berpengaruh positif dan signifikan terhadap kinerja karyawan. Hasil tersebut mengimplikasian bahwa kinerja karyawan dimaksimakan dengan menerapkan disiplin kerja yang baik tanpa adanya paksaan dari pimpinan dan berdasakan kesadaran diri terhadap tugas dan tanggung jawab. Disiplin kerja dapat diperoleh dengan mengerjakan tugas sesuai dengan intruksi atasan. Selain itu, kompensasi berpengaruh berpengaruh positif dan signifikan terhadap kinerja karyawan. Hal tersebut berimplikasi bahwa kinerja karyawan yang baik jika pemberian kompensasi dari perusahaan diberikan secara adil. Kinerja karyawan dapat diperoleh dengan memberikan sembako kepada karyawan.

\section{SIMPULAN}

Komunikasi berpengaruh positif dan signifikan terhadap Kinerja Karyawan Warung Mak Beng Cabang Ubud. Hal ini berarti jika Komunikasi semakin baik, maka Kinerja Karyawan semakin baik pula, sebaliknya jika Komunikasi semakin buruk maka Kinerja Karyawan akan semakin buruk. Disiplin kerja berpengaruh positif dan signifikan terhadap Kinerja Karyawan Warung Mak Beng Cabang Ubud. Hal ini berarti jika Disiplin Kerja semakin tinggi, maka Kinerja Karyawan semakin baik, sebaliknya jika Disiplin Kerja semakin rendah Kinerja Karyawan akan semakin buruk. Kompensasi berpengaruh positif dan signifikan terhadap Kinerja Karyawan Warung Mak Beng Cabang Ubud. Hal ini berarti jika Kompensasi semakin baik, maka Kinerja Karyawan semakin baik, sebaliknya jika Kompensasi semakin buruk maka Kinerja Karyawan akan semakin buruk pula.

Mengutamakan kejujuran dalam setiap pekerjaan yang dilakukan merupakan hal yang terpenting karena kejujuran merupakan hal yang paling utama yang harus dimiliki setiap orang dengan adanya kejujuran akan membuat orang merasa percaya dan yakin dengan pekerjaan yang mereka kerjakan sehingga karyawan akan lebih teliti dalam menyelesaikan pekerjaan, dan selalu memberikan gagasan yang inovatif sehingga perusahaan akan akan lebih mudah untuk mencapai tujuan dari perusahaannya. Membiasakan tegur sapa karyawan dengan atasan, tegur sapa sesama karyawan dan selalu berkoordinasi dengan sesama rekan kerja guna memecahkan masalah yang terjadi dalam pekerjaan. Sehingga karyawan akan selalu terbuka tentang permasalahan kerja tidak memiliki rasa canggung dengan atasan ataupun sesama rekan kerja dan meningkatkan kinerja.

Mengerjakan tugas sesuai dengan instruksi atasan mengenai pekerjaan dengan saling membantu dimana letak kesulitan yang memang tidak dapat di lakukan sendiri atau belum mengerti sehingga akan membuat karyawan merasa sanggup dalam mengerjakan pekerjaannya demi meningkatnya kinerja. Karyawan diharapkan menerima sembako disetiap tahunnya dari perusahaan sebaiknya lebih diperhatikan karena dapat membuat karyawan merasa senang dan merasa lebih dibantu dan di perhatikan sehingga karyawan akan lebih bersemangat bekerja disetiap tahunnya dan kinerja karyawan akan lebih meningkat. 


\section{REFERENSI}

Alan, K. D., \& Sudibya, I. G. A. (2019). Pengaruh Kepemimpinan Transaksional, Budaya Organisasi, dan Komunikasi Terhadap Kinerja Karyawan. E-Jurnal $\begin{array}{lllll}\text { Manajemen } \quad \text { Unud, } & 8(9), & 5847 \quad & 6866 .\end{array}$ https://doi.org/https://doi.org/10.24843/EJMUNUD.2019.v08.i09.p24

Angelina, V. (2015). The Influence Of Work Discipline, Leadership, and Motivation Employee Performance at PT. Trakindo Utama Manado. Jurnal EMBA, 3(3), 352-361.

Apalia, E. A. (2017). Effects of discipline management on employee performance in an organization: The case of county education office human resource department, Turkana County. International Academic Journal of Human Resource and Business Administration, 2(3), 1-18.

Ardiansyah, D. O. (2016). Pengaruh Komunikasi Terhadap Kinerja Karyawan Dengan Dimediasi Oleh Kepuasan Kerja. Jurnal Bisnis Dan Manajemen, 3(1), 16-30.

Atambo, D. W. N., \& Momanyi, D. K. (2016). Effects of Internal Communication on Employee Performance: A Case Study of Kenya Power and Lighting Company, South Nyanza Region, Kenya. Imperial Journal Interdesciplinary Research, 2(5), 328-340.

Bharata, A. (2016). The Enfluence of Compensation and Training Toward Work Discipline and its Impact On The Employees Performance In The Research Center Of Science and Technology (PUSPIPTEK). Journal The Winners, 17(1), 1-8.

Darma, P., \& Supriyanto, A. (2017). The Effect Of Compensation On Satisfaction and Employees Performance. Management and Economics Journal (MEC-J), $1(1), 66-74$.

Gabriel, M. C., Stella, M. I., \& Daniel, E. C. (2015). Impact of Effective Employee Performance Management on Organizational Productivity: A Study of Anambra State Civil Service System, Nigeria. The International Journal of Business \& Management, 3(11), 183-196.

Hadian, D. (2018). The Effect Of Work Climate and Work Discipline On Employee Performance (Study On One The 3 Star Hotels In Bandung). Jurnal Computech Dan Bisnis, 12(2), 162-170.

Hikmah, A. N., \& Hemmy, F. (2018). Pengaruh Disiplin kerja dan Kompetensi Terhadap Kinerja Pegawai (Studi Kasus Pada Pusat Penenlitian Kebijakan Pendidikan dan Kebudayaan Kementrian Pendidikan dan Kebudayaan). Jurnal Ekonomi Bisnis Indonesia, 13(2), 1-9. 
Kemby, E. F., Tewal, B., \& Walangitan, M. D. (2017). Pengaruh Kepemimpinan, Komunikasi dan Motivasi terhadap Kinerja Karyawan pada BP2RD. Provinsi Sulawesi Utara. Jurnal EMBA, 5(3), 3148-3159.

Kimani, N. J., Thomas, K. N., \& Arasa, R. (2017). Effect of Compensation Strategies on Employee Performance: A Case Study of Mombasa Cement Limited. International Journal of Innovative Social Sciences \& Humanities Research, 5(3), 25-42.

Kurniawan, H., \& Heryanto. (2019). Effect of Work Discipline and Work Environment on Employee Performance with Work Motivation as an Intervening Variable in Department of Tourism, Youth and Sport of Padang District. Archives of Business Research, 7(7), 88-101.

Lakoy, A. C. (2015). Pengaruh Komunikasi, Kerjasama Kelompok, dan Kreatifitas Terhadap Kinerja Karyawan Pada Hotel Aryaduta Manado. Jurnal EMBA, 3(3), 981-991.

Mendropa, K. A. (2019). Effect of Work Motivation and Discipline on Employee Performance of PT. Pos Indonesia Lubuk Pakam. Journal Of Management Science (JMAS), 1(4), 45-50.

Nabi, N. M., Foysol, K. M., \& Adnan, S. M. (2017). The Role and Impact of Business Communication on Employee Performances and Job Satisfactions: A Case Study on Karmasangsthan Bank Limited, Bangladesh. Arabian Journal of Business and Managemeny Review, 7(3), 2-8.

Nebo, C. S., Precious, N. N., \& Okonkwo, R. I. (2015). The Role of Fective Communication Organizational Performance: A Study of Namdi Azikiwe University, Awka. Review of Public Administration and Management, 4(8), 2315-7844.

Njoroge, S. W., \& Josephat, K. (2015). Influence of Compensation and Reward on Performance of Employees at Nakuru County Government. IOSR Journal of Business and Management, 17(1), 2319-7668.

Novita, D. (2015). Pengaruh kompensasi dan disiplin kerja terhadap prestasi kerja karyawan PT. Traktor Nusantara Cabang Padang. Jurnal Bisnis Dan Kewirausahaan, 4(1), 1-15.

Onuorah, A. N., Okeke, M. N., \& Ikechukwu, I. A. (2019). Compensation Manajemen and Employee Performance in Negeria. International Journal of Academic Research in Business and Social Sciences, 9(2), 384-298. 
Purba, R. (2018). The Effect of Communication and Motivation on Employee Performance at PT. Perkebunan Nusantara II Pagar Merbau. Enrichment: Journal of Management, 9(1), 4-6.

Puryatini., P., \& Sariyathi, N. K. (2017). Pengaruh Gaya Kepemimpinan Transformasional, Kerja Sama Tim dan Komunikasi Terhadap Kinerja Karyawan Warung Mina Cabang Renon. E-Journal Manajemen Universitas Udayana, 6(6), 3398-3420.

Ramli, A. H. (2019). Compensation, job satisfaction and employee performance in health services. Business and Entrepreneurial Review, 18(2), 177-186.

Rokhmawati, H. N. (2018). The Influence of Communication and Work Discipline on the Employee Performance (A Case Study of Employee Performance of Dwi Arsa Citra Persada Foundation in Yogyakarta, Indonesia). Journal of Arts, Science \& Commerce, 9(2), 6-13.

Sembiring, R. (2015). Pengaruh Komunikasi, Kepemimpinan, Motivasi dan Pelatihan Terhadap Kinerja Karyawan PT. Nipsea Paint And Chemicals Co.Ltd. Agrica. Agrica, 8(2), 1979-8164.

Srimiatun, \& Prihatinta, T. (2017). Pengaruh Komunikasi dan Konflik Terhadap Kinerja Karyawan Tenaga Kependidikan Politeknik Negeri Madiun. Jurnal Epicheirsi Manajemen, 1(1), 19-28.

Suprayitno. (2016). Pengaruh Disiplin Kerja, Lingkungan Kerja dan Motivasi Kerja Terhadap Kinerja Karyawan. Jurnal Sumber Daya Manusia, 2(1), 2334. 